\title{
Economic Viability Analysis of an Oral Anthelmintic Treatment for Cattle in Feedlot
}

\author{
Matheus Takemi Muchon Nakatani (Corresponding author) \\ Faculdade de Medicina Veterinária e Zootecnia, Universidade Federal de Mato Grosso \\ do Sul \\ 2443 Senador Filinto Muller Ave, Campo Grande, MS 79074-460, Brazil \\ Tel: +55-44-99869-7492Ｅ-mail: matheus_takemi@hotmail.com
}

Mario Henrique Conde

Faculdade de Medicina Veterinária e Zootecnia, Universidade Federal de Mato Grosso do Sul

2443 Senador Filinto Muller Ave, Campo Grande, MS 79074-460, Brazil

Tel: +55-67-99674-1968Ｅ-mail: marioh.vet@gmail.com

Mariana Green de Freitas

Faculdade de Medicina Veterinária e Zootecnia, Universidade Federal de Mato Grosso do Sul

2443 Senador Filinto Muller Ave, Campo Grande, MS 79074-460, Brazil

Tel: +55-67-99662-3334Ｅ-mail: marigreenf@hotmail.com

Flávia Carolina Fávero

Faculdade de Medicina Veterinária e Zootecnia, Universidade Federal de Mato Grosso do Sul

2443 Senador Filinto Muller Ave, Campo Grande, MS 79074-460, Brazil

Tel: +55-17-99259-8369Ｅ-mail: flaviafavero@zootecnista.com.br

Lucas Chaves de Paula

Faculdade de Medicina Veterinária e Zootecnia, Universidade Federal de Mato Grosso do Sul 
2443 Senador Filinto Muller Ave, Campo Grande, MS 79074-460, Brazil

Tel: +55-67- 9821-9969Ｅ-mail: 1-c-depaula@ hotmail.com

\author{
Marcos Da Silva Cabrera \\ Gpec - Gestao em Pecuaria
}

1275 Vinte Cinco de Dezembro St, Campo Grande, MS 79010-220, Brazil

Tel: +55-67- 3356-1506Ｅ-mail: gpec.cabrera@gmail.com

Marina de Nadai Bonin Gomes

Faculdade de Medicina Veterinária e Zootecnia, Universidade Federal de Mato Grosso do Sul

2443 Senador Filinto Muller Ave, Campo Grande, MS 79074-460, Brazil

Tel: +55-67-3345-3600Ｅ-mail: marina.bonin@ufms.br

\title{
Ricardo Carneiro Brumatti
}

Faculdade de Medicina Veterinária e Zootecnia, Universidade Federal de Mato Grosso do Sul

2443 Senador Filinto Muller Ave, Campo Grande, MS 79074-460, Brazil

Tel: +55-67-99227-1674 E-mail: rbrumatti@gmail.com

\author{
Daniel de Castro Rodrigues \\ Universidade Federal de Goiás \\ Esperança Ave, Goiânia, GO 74690-900, Brazil \\ Tel: +55-11-4613-4138Ｅ-mail: daniel.rodrigues2@merck.com
}

Fernando de Almeida Borges

Faculdade de Medicina Veterinária e Zootecnia, Universidade Federal de Mato Grosso do Sul

2443 Senador Filinto Muller Ave, Campo Grande, MS 79074-460, Brazil

Tel: +55-67-99244-4978Ｅ-mail: borgesvet@hotmail.com 
Received: December 9, 2020

doi:10.5296/jas.v9i2.18032
Accepted: March 8, 2021 Published: March 14, 2021

URL: https://doi.org/10.5296/jas.v9i2.18032

\begin{abstract}
The economic viability of a commercial oral anthelmintic suspension containing $10 \%$ fenbendazole was evaluated in Angus x Nelore cattle in a feedlot. Two groups of 37 animals (treated and non-treated) were formed. A random-block design was used based on initial weight, egg count per gram of feces (EPG) and carcass grade. EPG counts and the determination of weight were performed on Days 0, 42 and 122. Carcass grade and yield were determined on the day of slaughter. Economic viability was evaluated using cost-effectiveness, sensitivity and financial analyses, considering three economic scenarios: most likely $(M)$, optimistic $(O)$ and pessimistic $(P)$. The anthelmintic achieved $99.89 \%$ efficacy regarding EPG reduction. The animals exhibited an increase of $20.7 \mathrm{~kg}$ in live weight, $20.2 \mathrm{~kg}$ in live weight gain and $0.166 \mathrm{~kg}$ in daily weight gain $(\mathrm{p}<0.05)$. No effects were found on yield or carcass grade ( $\mathrm{p}>0.05$ ). The genus Haemonchus predominated at the onset of the study, whereas only the genus Cooperia was found after treatment. A net return of 14.60 USD per animal was found in the treated group, which remained viable under $O, M$ and $P$ scenarios, with respective differences of $18.92 \%, 12.86 \%$ and $91.15 \%$ in gross profit. The treatment was financially superior under all scenarios (real, $M, O$ and $P$ ), with reductions of $1.89,1.04,0.48$ and 16.39 years for the recovery of the initial investment. These results demonstrate the importance of economic analysis methods in the evaluation and selection of anthelmintics.
\end{abstract}

Keywords: gastrointestinal nematodes, benzimidazoles, anthelmintic resistance, carcass grade, weight gain

\title{
1. Introduction
}

Gastrointestinal nematodes (GINs) in cattle have cosmopolitan distribution and constitute a serious problem for livestock farming. Subclinical GIN infection can diminish economic viability through reductions in feed intake, feed conversion, growth performance, milk yield, carcass weight and fertility (Stromberg et al., 2012; Craig, 2018; Charlier et al., 2020). However, the perception of owners regarding the impact of GINs in feedlots is considered low (Yazwinski et al., 2015).

Economic losses can be even greater due to the difficulty controlling these parasites in different environmental contexts. According to Heckler \& Borges (2016), the tropical climate in Brazil is favorable to livestock farming, but also promotes the occurrence of GINs throughout the entire year, hindering the control of these organisms. In 2019, Brazilian beef cattle farming recorded the slaughter of 43.3 million animals and the entire agribusiness activity moved approximately 156.77 billion U.S. dollars (USD) (ABIEC, 2020). On the other hand, potential economic losses related to GINs in Brazilian cattle is estimated at 7.11 
million USD (Grisi et al., 2014).

The economic impact of GINs and the difficulty controlling these organisms are further aggravated by the use of taurine breeds (e.g., Angus), which are more susceptible to parasitic worms than zebu breeds (Peña et al., 2000). Moreover, some GIN populations in Brazil are resistant to drugs, such as macrocyclic lactones (MLs) (Souttelo et al., 2007; Borges et al., 2015; Ramos et al., 2016).

Despite their low efficacy, MLs are still widely used in Brazil due to their broad spectrum of action and long residual effect. However, the latter characteristic can lead to the presence of residual drugs in the meat and animal waste products (Lumaret \& Errouissi, 2002; Escribano et al., 2012), posing potential harm to consumers and the environment. In 2010 and 2014, the use of these drugs on animals in the end phase was banned by the Ministério da Agricultura, Pecuária e Abastecimento (MAPA [Brazilian Ministry of Agriculture and Livestock Farming]), but these decisions were revoked in 2011 and 2015. Such instability in the norms has a direct impact on production systems and disorients both producers and pharmaceutical companies.

The use of different drugs, such as benzimidazoles, is an important alternative. Benzimidazoles have a low frequency of anthelmintic resistance, are effective against field populations resistant to LMs (Souttelo et al., 2007; Shalaby 2013; Ramos et al., 2016) and enhance gains in animals in a feedlot (Ballweber et al., 2000; Smith et al., 2000; Reinhardt et al., 2006; Fazzio et al., 2014). These drugs also have a short residual effect, reducing the risks posed to human health, and the resulting metabolites are relatively harmless to the environment (Lumaret \& Errouissi, 2002), unlike LMs, which are eliminated unaltered and are found in considerable quantities in waste products at feedlots (Coleman et al., 2013).

Despite the advantages of benzimidazoles, little information is found on the economic viability of their use in feedlots. Only three cost-effectiveness studies have been conducted (Guichon et al., 2000; Smith et al., 2000; MacGregor et al., 2001). Moreover, only one of these studies considered variations in the economic scenario (Guichon et al., 2000), but did not employ an untreated control group in a context of low resistance to LMs. To date, no studies have used financial analysis methodologies to evaluate investments and returns related to anthelmintic treatment.

Economic sensitivity and financial analyses are as important as cost-effectiveness analysis, providing more comprehensive information on treatment by considering the impact of greater economic variation in accordance with the increase in the time range analyzed. Sensitivity analysis measures how the impact of uncertainties in one or more input variables can lead to uncertainties in output variables, thereby improving the prediction of a model (Pichery, 2014). This method employs several alternative outcomes to obtain a sense of the variability in returns, commonly considering 'most likely', 'optimistic' and 'pessimistic' scenarios and the returns associated with each for a given asset (Gitman \& Zutter, 2014). In financial analysis, Payback, net present value (NPV) and internal rate of return (IRR) are methods companies employ in managerial finance to analyze investment projects (Gitman \& Zutter, 2014). However, such methods could also be useful for the evaluation and selection of anthelmintics. 
Considering the tropical climate, the scarcity of studies in the region and the limited information on the economic aspects of treatments, the aim of the present investigation was to evaluate the economic viability of an oral fenbendazole considering weight gain and the carcass grade of cattle in a feedlot.

\section{Method}

\subsection{Study Setting}

This study was conducted on a beef cattle-raising property located in the municipality of Bodoquena in the state of Mato Grosso do Sul, Brazil (20²4'40.9"S, 56 52'10.9"W). The predominant climate of the region is tropical wet and dry, with a mean temperature of $23.1^{\circ} \mathrm{C}$ and annual mean precipitation of $1287 \mathrm{~mm}$ (EMBRAPA, 2006). The feedlot did not have a covered area. The ground was compact dirt. The trough was $40 \mathrm{~cm}$ linear/bull. Pen space allowance was $15 \mathrm{~m}^{2}$ per bull and the environment was enriched with hanging chains and water sprinklers.

\subsection{Animals and Management}

The animals (mixed-breed [Angus x Nelore] bulls with an initial age of 16 to 18 months and weight of 300 to $409 \mathrm{~kg}$ ) remained for a period of 30 days for feed adaptation in a semi-confined regimen prior to being transferred to the feedlot. The initial volume of feed offered was $8 \mathrm{~kg} /$ animal/day, followed by visual monitoring of consumption every three days, with an increase of $0.5 \mathrm{~kg} / \mathrm{animal}$, when necessary. The diet was composed of $82 \%$ whole corn, $3 \%$ cottonseed and 15\% protein mineral feed (Super Beef 500 - União Suplementação Animal). The animals had free access to water.

\subsection{Experimental Design}

Seventy-four animals were selected and divided into two groups of thirty-seven animals each. Each animal was considered an experimental unit. Distribution followed a randomized block design based on initial weight, mean fecal egg count (FEC) and carcass grade (determined using ultrasound, as described by BIF [2016]) in the pretreatment period (D-1). The animals were divided into two lots (Lot 1 and Lot 2) slaughtered on different days (Days 106 and 133 after treatment) in accordance with the management of the property. However, this division was planned so that both groups had the same number of animals in each lot. Thus, the length of stay was standardized as 122 days (average between Days 106 and 133). Live weight (LW), live weight gain (LWG) and daily weight gain (DWG) data for all animals in both groups were corrected based on the DWG of each animal.

\subsection{Treatments}

On D0, 23 animals from Lot 1 and 14 from Lot 2 were treated with 10\% fenbendazole (FBZ) (Panacur®, Merck Sharp \& Dohme Saúde Animal Ltda., batch number 012/16) with a dose of $5 \mathrm{mg} / \mathrm{kg}$ per LW administered orally with the aid of a hook applicator. The other 37 animals were divided in the same way and used as controls (CTRL), to which saline solution was administered at a dose of $1 \mathrm{~mL}$ for each $50 \mathrm{~kg}$ of $\mathrm{LW}$ subcutaneously in the neck region. 


\subsection{Determination of Weight and FEC}

Weight was determined and feces were collected one day prior to treatment (D-1) as well as 42 days after treatment (D+42) and prior to slaughter (Days 106 and 133 after treatment). The FEC was determined using the Mini-Flotac method (Barda et al., 2013) and coprocultures were prepared (Roberts \& O'Sullivan, 1950) for the determination of nematode genera using the identification key proposed by Ueno \& Gonçalves (1998).

\subsection{Carcass Grading, Maturity and Yield}

Ultrasound grading of the carcass on D-1 was only used for the division of the animals between the experimental groups on D0. At slaughter, carcass grade and maturity were determined by the employees of the slaughterhouse, who had been trained using the criteria established by MAPA Norm $n^{\circ} 9$ from May $4^{\text {th }}, 2004$ :

Distribution and quantity of cover fat determined through measurements at different sites of the carcass (on the $6^{\text {th }}, 9^{\text {th }}$ and $12^{\text {th }}$ ribs; in the dorsal and ventral parts of the latissimus dorsi and serratus dorsalis caudalis; in the lumbar region and in the thigh) and classified in the following categories: lean (1) - fat absent; sparse fat (2) - 1 to $3 \mathrm{~mm}$ in thickness; median fat (3) - more than 3 to $6 \mathrm{~mm}$ in thickness; uniform fat (4) - more than 6 to $10 \mathrm{~mm}$ in thickness; excessive fat (5) - more than $10 \mathrm{~mm}$ in thickness.

Maturity: established based on the examination of the incisors and classified in following categories: milk tooth $(d)$, two permanent teeth $(2 d)$, four permanent teeth $(4 d)$, six permanent teeth $(6 \mathrm{~d})$ or more than six permanent teeth $(8 \mathrm{~d})$.

Carcass yield (CY) was calculated by the sum of two half carcasses resulting from slaughter as follows:

$$
C Y=(C W \div L W) \times 100
$$

in which

$C Y=$ carcass yield, $C W=$ weight resulting from the sum of two half carcasses and $L W=$ live weight.

Carcass data (weight and grade) on four animals in the FBZ group and five in the CTRL group were lost.

\subsection{FEC Reduction Test}

The FEC reduction test was performed on 15 animals of the same breed and origin maintained under the same conditions that were not included in the groups. The animals were treated with 10\% FBZ following the manufacturer's instructions. The FEC was determined in samples collected on the day of treatment and the eighth day after treatment (D+8). This procedure was performed to avoid additional management during the study.

\subsection{Statistical Analysis}

The following variables were used in the evaluation: FEC, LW, LWG, DWG and CY. All 
variables were submitted to the Shapiro-Wilk normality test with alpha $=0.05$. FEC and CY exhibited non-normal distribution and were therefore log-transformed as follows:

$$
x=[\log (x+1)]
$$

in which

$x=$ fecal egg count of each animal in the group.

The Student's t-test was used to determine differences between the groups with regards to FEC, LW, LWG, DWG and CY. The Mann-Whitney test was used to determine differences in carcass grade between groups. Both tests were two-tailed, with the level of significance set to $5 \%(\mathrm{p}<0.05)$. The tests were executed using GraphPad Prism version 6.0 for Windows (GraphPad Software, San Diego, California, USA, www.graphpad.com). The percentage of effectiveness of FBZ regarding the reduction in the FEC was calculated using the method described by Coles et al. (1992), using the following equation:

$$
r=[1-(a \div b)] \times 100
$$

in which

$r=$ observed reduction, $a=$ mean FEC on $\mathrm{D}+8$ and $b=$ mean FEC on D0.

\subsection{Economic Analysis}

\subsubsection{Cost-Effectiveness Analysis}

Mean weight gains in the CTRL and FBZ groups corrected by the mean time in the feedlot $(\mathrm{D}+122)$ were used for the cost-effectiveness analysis. Acquisition, feeding, labor and deworming costs refer to the mean value in USD during the study period, which was fixed at 3.18 Reals (Brazilian currency) per USD. Gross income on the day of slaughter was calculated based on the value set for one $\mathrm{kg}$ of carcass (2.81 USD).

\subsubsection{Economic Sensitivity Analysis}

The economic sensitivity analysis (Gitman \& Zutter, 2014) was performed using the carcass price per $\mathrm{kg}$ in USD in a three-year period (January 2015 to December 2017), with the formation of the following economic scenarios: most likely $(M)=$ USD 2.89, optimistic $(O)=$ USD 3.04 and pessimistic $(P)=$ USD 2.67. The mean dollar value in the period was used for the $M$ scenario; the mean between the $M$ scenario and maximum value of the period was used for the $O$ scenario; and the mean between the $M$ scenario and minimum value of the period was used for the $P$ scenario.

Animal acquisition and labor costs were determined based on regional values. The deworming cost and gross income were calculated using the following formulas:

$$
d c=(47.25 \div v) \times(w \div d)
$$

in which

$d c=$ deworming cost, $47.25=$ regional mean of the product value in $\mathrm{USD}, v=$ volume of 
product, $w=$ mean of weight and $d=$ manufacturer-recommended dose.

$$
g i=(L W G \times c p) \times C Y
$$

in which

$g i=$ gross income, $L W G=$ mean of live weight gain, $c p=$ mean carcass price in USD per $\mathrm{kg}$ and $C Y=$ carcass yield.

The USD value, price per kg of carcass and price of the feed components (corn, cottonseed and protein mineral feed) were calculated using the databank of the Luiz de Queiroz Center for Advanced Studies in Applied Economics of the School of Agriculture of the University of São Paulo and the Mato Grosso Institute of Livestock Economics.

\subsubsection{Financial Analysis}

Financial analysis was conducted to evaluate the investment feasibility per animal in a situation in which animals are treated (FBZ) and untreated (CTRL), considering the cost-effectiveness analysis (real scenario) and the economic sensitivity analysis (scenarios $M$, $O$ and $P$ ) in an approach that weighs time and opportunity costs.

The capital expenditure was set to a period of 10 years. As each year has three production cycles of 480 animals each, the total number of animals produced per year was corrected to 1 440 .

The initial investment was set at 468.58 USD per animal in the FBZ group and 468.48 USD in this CTRL group, which represents the sum of the average regional price referring to the total land used, management structures (cattle yard, weighing scale, wire fencing, waterers and feeders), machinery (tractor and mixer-wagon) and the cost of oral drench syringe in the case of FBZ.

The financial results were obtained by estimates of future cash inflow using the net present value $(N P V)$, internal rate of return (IRR), profitability index $(P I)$ and Payback time, which were calculated using the following formulas:

$$
C \operatorname{Inf}=p-i
$$

in which

$p=$ profit, $C I n f=$ cash inflow and $i=$ initial investment;

$$
N P V=\left(\sum C \operatorname{Inf}_{n} \div(1+M A R R)^{n}\right)-i
$$

in which

$N P V=$ net present value, $n=$ number of time periods and $M A R R=$ minimum attractive rate of return (interest rate of $0.64 \%$ accumulated over four months);

$$
0=\left(\sum \operatorname{CInf}_{n} \div(1+I R R)^{n}\right)-i
$$

in which 
$I R R=$ internal rate of return (necessary rate to nullify $N P V$ );

$$
P I=N P V \div i
$$

in which

$P I=$ profitability index;

$$
\text { Payback }=i \div \text { CInf }
$$

in which

Payback $=$ time required to recover the initial investment.

Results related to $N V P, I R R, P I$ and Payback in both situations under real, $M, O$ and $P$ scenarios were compared to establish the most profitable investment. Thus, an investment is acceptable if $N V P \geq 0, I R R$ is positive and $P I \geq 1$.

\section{Results}

The groups were similar with regards to FEC and LW on D0 (Table 1). No significant difference between groups was found with regards to FEC on D+42 and D+122 ( $>$ > 0.05) due to the drastic reduction in FEC in the CTRL group on D+42. The counts remained low through to the days prior to slaughter. In the comparison of D0 and D+42, an 8.4-kg increase in LWG was found in the FBZ group, but this difference was non-significant ( $p=0.0580$ ). The standard deviation (SD) was $17.5 \mathrm{~kg}$ for FBZ and $19.8 \mathrm{~kg}$ CTRL, which represents a coefficient of variation (CV) of $19.34 \%$ and $24.14 \%$, respectively.

The increases of $20.7 \mathrm{~kg}$ in LW, $20.2 \mathrm{~kg}$ in LWG and $0.166 \mathrm{~kg}$ in DWG found at D+122 were significant ( $\mathrm{p}=0.019,0.007$ and 0.007 , respectively). The CV in the FBZ $(15.55 \%)$ and CTRL (15.69\%) groups were related to LWG. DWG remained higher compared to LW (FBZ $=6.52 \%$ and CTRL $=6.81 \%)$. Carcass yield was similar between the treated animals and control group $(\mathrm{p}=0.19)$ and the $\mathrm{CV}$ was low for both $(\mathrm{FBZ}=4.22 \%$ and $\mathrm{CTRL}=6.18 \%)$.

Table 1. Variables in different treatments according to evaluation day of Nelore $\mathrm{x}$ Angus

\begin{tabular}{|c|c|c|c|c|c|c|c|c|c|c|c|}
\hline \multirow[b]{2}{*}{ TRT } & & \multicolumn{2}{|c|}{ D0 } & \multicolumn{3}{|c|}{$\mathrm{D}+42$} & \multicolumn{5}{|c|}{$\mathrm{D}+122$} \\
\hline & & $\begin{array}{l}\mathrm{LW} \\
(\mathrm{kg})\end{array}$ & FEC & $\begin{array}{l}\mathrm{LW} \\
(\mathrm{kg})\end{array}$ & $\begin{array}{c}\text { LWG } \\
(\mathrm{kg})\end{array}$ & FEC & $\begin{array}{l}\mathrm{LW} \\
(\mathrm{kg})\end{array}$ & $\begin{array}{l}\text { LWG } \\
(\mathrm{kg})\end{array}$ & FEC & $\begin{array}{c}\text { DWG } \\
(\mathrm{kg})\end{array}$ & $\begin{array}{l}\text { CY } \\
(\%)\end{array}$ \\
\hline \multirow[t]{2}{*}{ FBZ } & Mean & $\begin{array}{c}346.7 \\
\mathrm{a}\end{array}$ & $92.8^{\mathrm{a}}$ & $436.1^{\mathrm{a}}$ & $90.4^{\mathrm{a}}$ & $2.5^{\mathrm{a}}$ & $\begin{array}{c}555.1 \\
\text { a }\end{array}$ & $208.4^{\mathrm{a}}$ & $0.5^{\mathrm{a}}$ & $1.71^{\mathrm{a}}$ & $54.2^{\mathrm{a}}$ \\
\hline & $\mathrm{SD}$ & 21.6 & 125.4 & 31.6 & 17.5 & 10.0 & 36.2 & 32.4 & 1.9 & 0.3 & 2.3 \\
\hline \multirow{2}{*}{$\begin{array}{c}\text { CTR } \\
\text { L }\end{array}$} & Mean & $\begin{array}{c}346.2 \\
\mathrm{a}\end{array}$ & $\begin{array}{c}133.1 \\
\mathrm{a}\end{array}$ & $428.2^{\mathrm{a}}$ & $82.0^{\mathrm{a}}$ & $1.5^{\mathrm{a}}$ & $\begin{array}{c}534.4 \\
\text { b }\end{array}$ & $188.2^{\mathrm{b}}$ & $0.7^{\mathrm{a}}$ & $1.54^{\mathrm{b}}$ & $55.2^{\mathrm{a}}$ \\
\hline & SD & 27.4 & 226.2 & 31.4 & 19.8 & 4.6 & 36.4 & 29.5 & 1.8 & 0.2 & 3.4 \\
\hline
\end{tabular}
calves in feedlot

Note: Different lowercase letters $\left({ }^{\mathrm{a}, \mathrm{b}}\right)$ in same column denote significant difference $(\mathrm{p}<0.05$, Student's t-test); TRT = treatments; FBZ = fenbendazole group; CTRL = control group; SD = standard deviation; FEC = fecal egg count; $\mathrm{LW}=$ live weight $\mathrm{LWG}=$ live weight gain; $\mathrm{DWG}$ 
= daily weight gain; $\mathrm{CY}=$ carcass yield.

No significant difference between groups was found for fat content ( $p=0.96)$, as an even distribution of animals was found among the different categories (Table 2). Both groups also had similar distribution with regards to maturity, with 55\% of all animals in category $\mathrm{d}$ and $45 \%$ in category $2 \mathrm{~d}$.

Table 2. Carcass grades and positional measure for fat coverage in treatments with Nelore $\mathrm{x}$ Angus calves in feedlot

\begin{tabular}{|c|c|c|c|c|c|c|c|c|}
\hline \multirow{2}{*}{ Treatments } & \multicolumn{5}{|c|}{ Carcass category $(\%)$} & \multirow{2}{*}{ Median } & \multirow{2}{*}{ Minimum } & \multirow{2}{*}{ Maximum } \\
\hline & 1 & 2 & 3 & 4 & 5 & & & \\
\hline FBZ & 0 & 51.52 & 45.45 & 3.03 & 0 & 2 & 2 & 4 \\
\hline CTRL & 0 & 50.00 & 46.88 & 3.12 & 0 & 2.5 & 2 & 4 \\
\hline
\end{tabular}

Note: $\mathrm{FBZ}=$ fenbendazole group; $\mathrm{CTRL}=$ control group.

The anthelmintic achieved $99.89 \%$ effectiveness at reducing the FEC on D+8. The coprocultures of the samples collected on D0 demonstrated a predominance of the genus Haemonchus, followed by the genera Cooperia and Oesophagostomum. Only larvae of the genus Cooperia were found in the coprocultures performed on D+42 and D+122 (Figure 1).

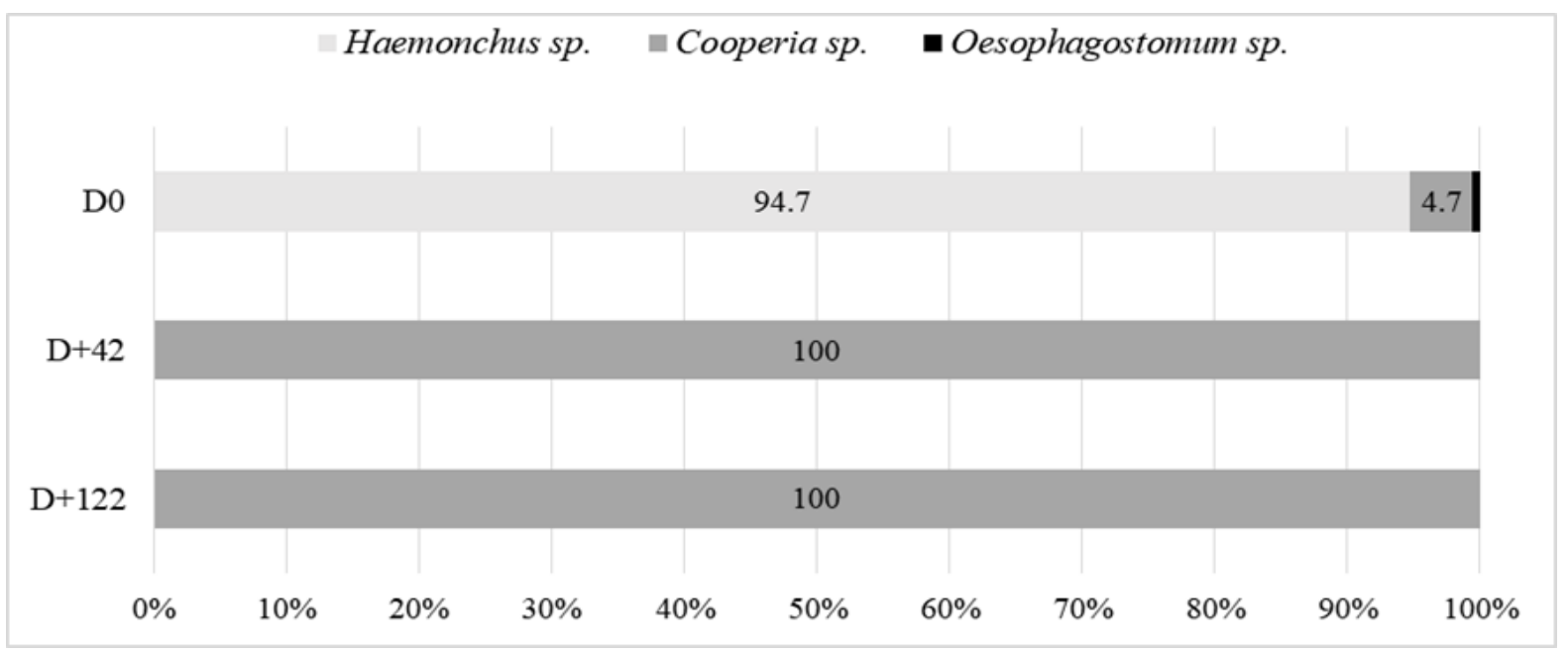

Figure 1. Proportion of gastrointestinal nematode genera retrieved from coprocultures

In the cost-effectiveness analysis, gross income in the FBZ and CTRL groups was 844.44 and 828.92 USD, respectively. The deworming cost in the FBZ group was 0.92 USD per animal. However, the gross profit was 71.09 USD, which was 14.60 USD (25.85\%) higher than the gross profit in the CTRL group. The animal acquisition, feeding, labor and fuel costs were the same in both groups, since all animals were submitted to the same conditions (Table 3). 
Table 3. Cost-effectiveness of treatments

\begin{tabular}{|c|c|c|c|}
\hline & \multirow{2}{*}{ Variables (USD) } & \multicolumn{2}{|c|}{ Treatments } \\
\hline & & FBZ & CTRL \\
\hline & Gross income & 844.44 & 828.92 \\
\hline \multirow{5}{*}{ Costs } & Acquisition & 531.79 & 531.79 \\
\hline & Feeding & 230.54 & 230.54 \\
\hline & Labor & 4.56 & 4.56 \\
\hline & Deworming & 0.92 & 0 \\
\hline & Fuel & 5.54 & 5.54 \\
\hline \multirow{2}{*}{ Results } & Operational cost & 773.35 & 772.43 \\
\hline & Gross profit & 71.09 & 56.49 \\
\hline
\end{tabular}

Note: $\mathrm{FBZ}=$ fenbendazole group; $\mathrm{CTRL}=$ control group.

In the sensitivity analysis, the gross income in the FBZ group was $867.81,912.43$ and 802.35 USD in the $M, O$ and $P$ scenarios, respectively (Table 4). These figures respectively correspond to increases of 15.03 (18.92\%), 15.85 (12.86\%) and $13.83(91.15 \%)$ USD in gross profit per animal compared to the CTRL group.

Table 4. Economic sensitivity analysis of treatments

\begin{tabular}{|c|c|c|c|c|}
\hline \multirow{2}{*}{ Treatments } & \multirow{2}{*}{$\begin{array}{c}\text { Economic } \\
\text { scenarios }\end{array}$} & \multicolumn{3}{|c|}{ Variables (USD) } \\
\hline & & Gross income & Operational cost & Gross profit \\
\hline \multirow{3}{*}{ FBZ } & $M$ & 867.81 & & 94.46 \\
\hline & $O$ & 912.43 & 773.35 & 139.08 \\
\hline & $P$ & 802.35 & & 29.00 \\
\hline \multirow{3}{*}{ CTRL } & $M$ & 851.87 & & 79.43 \\
\hline & $O$ & 895.66 & 772.43 & 123.23 \\
\hline & $P$ & 787.60 & & 15.17 \\
\hline
\end{tabular}

Note $: \mathrm{FBZ}=$ fenbendazole group; $\mathrm{CTRL}=$ control group; $M=$ most likely; $O=$ optimistic; $P$ $=$ pessimistic.

In the financial analysis, the FBZ was superior to the CTRL under all scenarios (Table 5). Both the FBZ and CTRL groups had a negative indication in terms of the feasibility of investment only in the $P$ scenario. The total initial investment was 674755.20 USD in FBZ and 674611.20 USD in CTRL. The only difference between groups regarding the initial investment was the oral drench syringe used in the FBZ group, which resulted in an increase of 143.50 USD (0.10 USD per animal). 
Table 5. Financial analysis of treatments

\begin{tabular}{|c|c|c|c|c|c|}
\hline \multirow{2}{*}{$\begin{array}{c}\text { Treatment } \\
\text { situation }\end{array}$} & \multirow{2}{*}{$\begin{array}{l}\text { Economic } \\
\text { scenarios }\end{array}$} & \multicolumn{4}{|c|}{ Variables } \\
\hline & & $N P V(\mathrm{USD})$ & $\operatorname{IRR}(\%)$ & $P I$ & Payback (years) \\
\hline \multirow{4}{*}{ FBZ } & Real & 169.99 & 8.40 & 1.36 & 7.34 \\
\hline & $M$ & 379.92 & 15.31 & 1.51 & 5.52 \\
\hline & $O$ & 780.72 & 26.95 & 2.67 & 3.75 \\
\hline & $P$ & -208.08 & -7.89 & 0.56 & 17.99 \\
\hline \multirow{4}{*}{ CTRL } & Real & 38.95 & 3.56 & 1.08 & 9.23 \\
\hline & $M$ & 245.10 & 10.97 & 1.52 & 6.75 \\
\hline & $O$ & 638.45 & 22.98 & 2.36 & 4.23 \\
\hline & $P$ & -332.21 & -16.56 & 0.29 & 34.38 \\
\hline
\end{tabular}

Note: $\mathrm{FBZ}=$ animals treated with fenbendazole; $\mathrm{CTRL}=$ untreated animals; $M=$ most likely; $O=$ optimistic; $P=$ pessimistic; $N P V=$ net present value; $I R R=$ internal rate of return; $P I=$ profitability index; Payback $=$ time required to recover investment cost.

Regarding the economic scenarios at the end of 10 years, the difference between treatments related to $N P V$ was $131.04,134.82,142.27$ and 124.13 USD per animal in the real, $M, O$ and $P$ scenarios, respectively. The difference in $I R R$ was 4.84, 4.34, 3.97 and $8.67 \%$ in the real, $M$, $O$ and $P$ scenarios, respectively. Regarding Payback time, the CTRL group required 1.89 more years $(\approx 23$ months) compared to the FBZ group to recover the initial investment in the real scenario, 1.04 more years $(\approx 13$ months $)$ in the $M$ scenario, 0.48 more years $(\approx 6$ months) in the $O$ scenario, and 16.39 more years ( $\approx 197$ months) in the $P$ scenario.

\section{Discussion}

The productive increase in the animals treated with $10 \%$ FBZ administered orally in the present study is compatible with results described by Fazzio et al. (2014), who found a significant reduction in the FEC on Day 21 post-treatment and a consequent increase in LWG on Day 98 post-treatment in a group treated with ricobendazole compared to an untreated group. This is a consequence of the high susceptibility of GINs to benzimidazoles due to the lower frequency of the use of these drugs in Brazil (Soutello et al., 2007). According to Gasbarre (2014), a feedlot is the ideal setting for the use of different drugs and combinations, considering the presence of resistant parasites from previous phases together with the low risk of propagating anthelmintic resistance, since the animals are slaughtered at the end of the process. Besides the increase in production, high effectiveness and low risk of exposure to residual drugs, oral administration eliminates the possibility of a local reaction generated by injected formulations.

The reduction in the FEC in the untreated group is in agreement with data reported by Smith et al. (2000). This reduction is partially due to the low probability of re-infection in animals kept in a feedlot, along with the high protein-energy diet. According to Hoste \& Torres-Acosta (2011), feed supplementation enhances the host response to GINs. Moreover, older animals in prolonged contact with GINs tend to exhibit reductions in the parasite load and the excretion of eggs due to the development of the immune response. 
No significant difference was found in the animals treated with FBZ with regards to carcass grade. According to Ceï et al. (2015), the proportion of fat is not completely dependent on the level of infection, as animals are able to preserve adipose tissue. Moreover, parasite control in phases prior to termination can exert a major impact on this variable. Indeed, Smith et al. (2000) report superior results in animals treated during the pasture phase compared to those treated only upon entering the feedlot.

The better performance of the FBZ group in the cost-effectiveness analysis is due to the low cost and high profitability of the treatment per animal. Smith et al. (2000) report similar findings. Although not always employed, sensitivity analysis can provide more detailed information on treatment by considering different economic scenarios. In the present study, the difference in profitability was lower in the better economic scenario due to the increase in the price per kg of carcass. Guichon et al. (2000) report a similar result using ivermectin in a situation of low anthelmintic resistance. Thus, more significant differences are found in less favorable economic scenarios, when highly effective parasite control is all-the-more important.

Although the CTRL group had positive indications in the real, $M$ and $O$ scenarios, the results were inferior to those found in the FBZ group and a longer period would be needed to achieve positive results in the case of the $P$ scenario. An investment is the expenditure of money with the expectation of a return over time. The NPV method takes into account the cash flow and time value of money. Thus, an investment only should be undertaken if the $N P V$ of the cash flow is greater than the investment (Gitman \& Zutter, 2014). The PI is a simplified variation of the NPV. A $P I$ greater than 1.0 corresponds to positive cash flow, while $I R R$ is the rate of return that will be earned, which is an assurance that at least the necessary return will be obtained (Gitman \& Zutter, 2014). These methods quantify the viability of an investment and provide data to facilitate comparisons between projects. In present study, the financial superiority of the investment in the FBZ group over the CTRL group over a period of 10 years was clearly demonstrated.

In financial analysis, Payback measures how quickly the initial investment can be recovered and helps determine exposure to risk, as a longer wait to recover invested funds increases the risk (Gitman \& Zutter, 2014). The negative indications of the $P$ scenario in both the FBZ and CTRL groups was related to the small estimated profitability in period analyzed, as a period longer than the previously established 10 years would be necessary to achieve a positive result.

Negative NPV, IRR and PI and greater Payback severely reduces the attractiveness of a new investment. However, in an operation that is already being performed, it is important to invest in effective deworming to make the system more profitable or reduce losses. In the present study, a small investment of 0.10 USD added to the cost of 0.92 USD per animal resulted in a more than 16-year reduction in Payback time.

All of these economic analysis methods need to be applied together with parasitological evaluations (FEC reduction test) and zootechnical indices (carcass grade, CY, LWG and DWG) to assist owners and veterinarians in both the decision to invest in more efficient 
deworming and selecting the most effective anthelmintic.

A significant increase in production was found in beef cattle submitted to treatment with oral FBZ upon entering the feedlot. Moreover, the administration of this drug is highly viable from the economic standpoint. Remaining GINs in cattle exert a strong negative impact on production and profit. However, the control of these parasites does not always lead to an improvement in carcass grade.

\section{References}

ABIEC. (2020). Beef Report - Perfil da Pecuária no Brasil 2020. São Paulo, SP: Associação Brasileira das Indústrias Exportadoras de Carnes. Retrieved from http://abiec.com.br/publicacoes/beef-report-2020/

Ballweber, L. R., Brown, J., Hawkins, J., Bechtol, D. T., Black, S., Alva, R., \& Plue, R. E. (2000). Comparison of Ivermectin SR Bolus, Benzimidazole Anthelmintics, and Topical Fenthion on Productivity of Stocker Cattle From Grazing Through Feedlot. Veterinary Therapeutics, 1(3), 192-198. PMID: 19757582

Barda, B. D., Rinaldi, L., Ianniello, D., Zepherine, H., Salvo, F., Sadutshang, T., Cringoli, G., Clementi, M., \& Albonico, M. (2013). Mini-FLOTAC, an innovative direct diagnostic technique for intestinal parasitic infections: experience from the field. PLOS Neglected Tropical Diseases, 7(8), e2344. https://doi.org/10.1371/journal.pntd.0002344

BIF. (2016). Guidelines For Uniform Beef Improvement Programs Ninth Edition. Prairie, MS: Beef Improvement Federation. Retrieved from https://beefimprovement.org/

Borges, F. A., Borges, D. G. L., Heckler, R. P., Neves, J. P., Lopes, F. G. \& Onizuka, M. K. (2015). Multispecies resistance of cattle gastrointestinal nematodes to long-acting avermectin formulations in Mato Grosso do Sul. Veterinary Parasitology, 212(3-4), 299-302. https://doi.org/10.1016/j.vetpar.2015.06.015

Ceï, W., Hiol, A., Gobardhan, J., Nepos, A., Felicite, Y., Mahieu, M., \& Alexandre, G. (2015). Growth and carcass attributes of growing Creole kids according to experimental infection level and type of diet. Tropical Animal Health and Production, 47, 953-960.

Charlier, J., Höglund, J., Morgan, E. R., Geldhof, P., Vercruysse, J., \& Claerebout, E. (2020). Biology and epidemiology of gastrointestinal nematodes in cattle. Veterinary Clinics of North America: Food Animal Practice, 36, 1-15. https://doi.org/10.1016/j.cvfa.2019.11.001

Coleman, H. M., Trinh, T., Le-Minh, N., Klein, M., Roser, D. J., Tucker, R. W., ... Khan, S. J. (2013). Occurrence of ectoparasiticides in Australian beef cattle feedlot wastes. Environmental Pollution, 174, 265-272. https://doi.org/10.1016/j.envpol.2012.11.018

Coles, G. C., Bauer, C., Borgsteede, F. H. M., Geerts, S., Klei, T. R., Taylor, M. A., \& Waller, P. J. (1992). World Association for the Advancement of Veterinary Parasitology (W.A.A.V.P.) methods for the detection of anthelmintic resistance in nematodes of veterinary importance. Veterinary Parasitology, 44, 35-44. https://doi.org/10.1016/0304-4017(92)90141-U 


\section{$\triangle$ Macrothink}

Journal of Agricultural Studies

ISSN 2166-0379

2021, Vol. 9, No. 2

Craig, T. M. (2018). Gastrointestinal Nematodes, Diagnosis and Control. Veterinary Clinics of North America: Food Animal Practice, 34(1), 185-199. https://doi.org/10.1016/j.cvfa.2017.10.008

EMBRAPA. (2006). Boletim de Pesquisa e Desenvolvimento 99: Caracterização Climática e Aptidão das Culturas Anuais e Perenes no Zoneamento Pedoclimático do Estado do Mato Grosso do Sul - $1^{a}$ fase. Rio de Janeiro, RJ: Empresa Brasileira de Pesquisa Agropecuária. Retrieved from https://www.infoteca.cnptia.embrapa.br/infoteca/handle/doc/855927

Escribano, M., San Andrés, M. I., de Lucas, J. J., \& González-Canga, A. (2012). Ivermectin Residue Depletion in Food Producing Species and its Presence in Animal Foodstuffs With a View to Human Safety. Current Pharmaceutical Biotechnology, 13, 987-998. https://doi.org/10.2174/138920112800399121

Fazzio, L. E., Sánchez, R. O., Streitenberger, N., Galvan, W. R., Giudici, C. J., \& Gimeno, E. J. (2014). The effect of anthelmintic resistance on the productivity in feedlot cattle. Veterinary Parasitology, 206, 240-245. https://doi.org/10.1016/j.vetpar.2014.10.010

Gasbarre, L. C. (2014). Anthelmintic resistance in cattle nematodes in the US. Veterinary Parasitology, 204(1-2), 3-11. https://doi.org/10.1016/j.vetpar.2014.03.017

Gitman, L. J., \& Zutter, C. J. (2014). Principles of Managerial Finance. (14 ${ }^{\text {th }}$, global ed.) Harlow: Pearson. 936 p.

Grisi, L., Leite, C. R., Martins, J. R. S., Barros, A. T. M., Andreotti, R., Cançado, P. H. D., ... Villela, H. S. (2014). Reassessment of the potential economic impact of cattle parasites in Brazil. Brazilian Journal of Veterinary Parasitology, 23(2), 150-156. https://doi.org/10.1590/S1984-29612014042

Guichon, P. T., Jim, G. K., Booker, C. W., Schunicht, O. C., Wildman, B. K., \& Brown, J. R. (2000). Relative cost-effectiveness of treatment of feedlot calves with ivermectin versus treatment with a combination of fenbendazole, permethrin, and fenthion. Journal of the American Veterinary Medical Association, 216, 1965-1969. https://doi.org/10.2460/javma.2000.216.1965

Heckler, R. P., \& Borges, F. A. (2016). Climate variations and the environmental population of gastrointestinal nematodes of ruminants. Nematoda, 3, e012016. https://doi.org/10.4322/nematoda.00116

Hoste, H., \& Torres-Acosta, J. F. J. (2011). Non chemical control of helminths in ruminants: Adapting solutions for changing worms in a changing world. Veterinary Parasitology, 180, 144-154. https://doi.org/10.1016/j.vetpar.2011.05.035

Lumaret, J. P., \& Errouissi, F. (2002). Use of anthelmintics in herbivores and evaluation of risks for the non target fauna of pastures. Veterinary Research, 33, 547-562. https://doi.org/10.1051/vetres:2002038

MacGregor, D. S., Yoder, D. R., \& Rew, R. S. (2001). Impact of doramectin treatment at the time of feedlot entry on the productivity of yearling steers with natural nematode infections. 
American Journal of Veterinary Research, 62, 622-624. https://doi.org/10.2460/ajvr.2001.62.622

MAPA. (2004). Sistema Brasileiro de Classificação de Carcaças de Bovinos. (MAPA Instrução Normativa No. 09, de 1 de maio de 2004). Brasília, DF: Ministério da Agricultura, $\begin{array}{llll}\text { Pecuária } & \mathrm{e} & \text { Abastecimento } & \text { Retrieved }\end{array}$ https://www.jusbrasil.com.br/diarios/814817/pg-10-secao-1-diario-oficial-da-uniao-dou-de-2 $2-12-2003$

Peña, M. T., Miller, J. E., Wyatt, W., \& Kearney, M. T. (2000). Differences in susceptibility to gastrointestinal nematode infection between Angus and Brangus cattle in south Louisiana. Veterinary Parasitology, 89, 51-61. https://doi.org/10.1016/S0304-4017(99)00229-0

Pichery, C. (2014). Sensitivity Analysis. Encyclopedia of Toxicology, 4, 236-237. https://doi.org/10.1016/B978-0-12-386454-3.00431-0

Ramos, F., Portella, L. P., Rodrigues, F. D., Reginato, C. Z., Pötter, L., Cezar, A. S., ... Vogel, F. S. (2016). Anthelmintic resistance in gastrointestinal nematodes of beef cattle in the state of Rio Grande do Sul, Brazil. International Journal for Parasitology: Drugs and drug resistance, 6, 93-101. https://doi.org/10.1016/j.ijpddr.2016.02.002

Reinhardt, C. D., Hutcheson, J. P., \& Nichols, W. T. (2006). A fenbendazole oral drench in addition to an ivermectin pour-on reduces parasite burden and improves feedlot and carcass performance of finishing heifers compared with endectocides alone. Journal of Animal Science, 84, 2243-2250. https://doi.org/10.2527/jas.2005-598

Roberts, F. H. S., \& O'Sullivan, P. J. (1950). Methods for egg counts and larval cultures for strongyles infesting the gastro-intestinal tract of cattle. Australian Journal of Agricultural Research, 1, 99. https://doi.org/10.1071/AR9500099

Shalaby, H. A. (2013). Antihelmintics resistance; How to overcome it? Iranian Journal Parasitology, 8, 18-32. PMID: 23682256

Smith, R., Rogers, K., Huse, S., Wray, M., Brandt, B., Hutcheson, J., .. Rains, J. (2000). Pasture deworming and(or) subsequent feedlot deworming with fenbendazole (Safe-Guard) I. Effects on grazing performance, feedlot performance, and carcass traits of yearling steers. Bovine Practitioner, 34(2), 104-114. https://doi.org/10.21423/bovine-vol34no2p104-114

Soutello, R. G. V., Seno, M. C. Z., \& Amarante, A. F. T. (2007). Anthelmintic resistance in cattle nematodes in northwestern São Paulo State, Brazil. Veterinary Parasitology, 148, 360-364. https://doi.org/10.1016/j.vetpar.2007.06.023

Stromberg, B. E., Gasbarre, L. C., Waite, A., Bechtol, D. T., Brown, M. S., Robin-son, N. A., ... Newcomb, H. (2012). Cooperia punctata: effect on cattle productivity? Veterinary Parasitology, 183, 284-291. https://doi.org/10.1016/j.vetpar.2011.07.030

Ueno, H., \& Gonçalves, P. C. (1998). Manual para diagnóstico de helmintoses de ruminantes. ( $4^{\text {th }}$ ed.) Tokyo: Japan International Cooperation Agency, 143 p. 


\section{Macrothink}

Journal of Agricultural Studies

ISSN 2166-0379 2021, Vol. 9, No. 2

Yazwinski, T. A., Tucker, C. A., Powell, J., Beck, P., Wray, E., \& Weingartz, C. (2015). Current Status of Parasite Control at the Feed Yard. Veterinary Clinics of North America: Food Animal Practice, 31, 229-245. https://doi.org/10.1016/j.cvfa.2015.03.005

\section{Copyright Disclaimer}

Copyright for this article is retained by the author(s), with first publication rights granted to the journal.

This is an open-access article distributed under the terms and conditions of the Creative Commons Attribution license (http://creativecommons.org/licenses/by/4.0/). 